\title{
MANAGEMENT OF WINTER AND SUMMER WEEDS IN VINEYARDS AND OLIVE GROVES WITH AN ECOLOGICAL FERTILIZER WITH HERBICIDAL PROPERTIES
}

\author{
GESTÃO DE INFESTANTES DE INVERNO E PRIMAVERA EM VINHA E OLIVAL COM UM \\ FERTILIZANTE ECOLÓGICO COM PROPRIEDADES HERBICIDAS
}

\author{
António Barreira ${ }^{1}$, Margarida Arrobas ${ }^{1}$, Carlos $\operatorname{Cardoso}^{2}$, M. Ângelo Rodrigues ${ }^{1 *}$ \\ ${ }^{1}$ Centro de Investigação de Montanha (CIMO), Instituto Politécnico de Bragança, Campus Santa Apolónia, $5300-253$ Bragança, Portugal. \\ ${ }^{2}$ Motivos Campestres - Unipessoal, Lda, Rua 638, Zona Industrial, 5370-327 Mirandela, Portugal
}

*corresponding author: Telef: +351 273303260, e-mail: angelor@ipb.pt

(Received 13.08.2018. Accepted 27.05.2019)

SUMMARY

Weeds reduce crop yields and require annual measures of control, although they can provide important ecological benefits. In this work, the

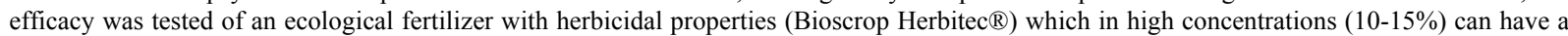
similar effect to a contact herbicide. The composition of the product is $6.0 \%$ of water-soluble potassium oxide, $54.7 \%$ of organic acids and 39.3 $\%$ of dispersants and diluents. The product was tested in six field trials during two years, which included two vineyards and two olive orchards and winter and spring vegetation. In each experiment three treatments were imposed, being the product applied at the concentrations of $10 \%$ and $15 \%$ and a non-treated control. In treated plots, the entire ground surface (rows and inter-rows) was sprayed. The evaluation of the effect of the treatments on vegetation was assessed by the pin point and grid methods which consisted of determining the percentage of damaged and not damaged vegetation and bare soil. The production of dry biomass of weeds was also evaluated as a measure of the persistence of the damage on vegetation. The floristic composition of the stands was also recorded to evaluate the specific susceptibility of the weeds to the different treatments. The results showed that the product severely damaged the vegetation, and the effect persisted for more than a month. The application of the product caused a severe reduction in the aboveground biomass while keeping the soil protected, showing a useful compromise between the reduction in weed competition and the maintenance of ground cover. Some species were severely damaged while others seemed to have benefited in relative terms, suggesting that the effectiveness of the product will be dependent on the weed species present.

\section{RESUMO}

As infestantes reduzem a produtividade das culturas e requerem medidas anuais de combate, embora também possam fornecer importantes serviços ecossistémicos. Neste trabalho foi testada a eficácia de um produto ecológico (Bioscrop Herbitec®) que, em altas concentrações (10$15 \%$ ), pode ter um efeito semelhante ao de um herbicida de contato. O produto contém $6,0 \%$ de óxido de potássio solúvel em água, $54,7 \%$ de ácidos orgânicos e $39,3 \%$ de dispersantes e diluentes. O produto foi testado em seis ensaios de campo, em duas vinhas e dois olivais e sobre vegetação de inverno e de primavera. Em cada ensaio foram testados três tratamentos, correspondentes à aplicação do produto em duas concentrações (10 e 15\%) e uma modalidade testemunha. Nos talhões tratados o produto foi aplicado nas linhas e entrelinhas. O efeito dos tratamentos na vegetação foi avaliado pelos métodos do ponto quadrado e da grelha, que consistiram em determinar o grau de cobertura do solo com vegetação danificada, não danificada e solo nu. A produção de matéria seca das infestantes foi também avaliada como medida da persistência do dano na vegetação. A composição florística dos cobertos foi também registada como forma de avaliar a suscetibilidade específica das infestantes aos diferentes tratamentos. Os resultados mostraram que o produto danificou severamente a vegetação e o efeito persistiu por mais de um mês. A aplicação do produto causou uma redução significativa da biomassa aérea, mas manteve o solo protegido, mostrando um equilíbrio interessante entre a redução da competição das infestantes e a proteção do solo. Algumas espécies foram fortemente danificadas, enquanto outras parecem ter beneficiado em termos relativos, sugerindo que a eficácia do produto dependerá das espécies infestantes presentes

Key words: Vitis vinifera; Olea europaea; ecological weed management; cover cropping.

Palavras-chave: Vitis vinifera; Olea europaea; gestão ecológica de infestantes; enrelvamento do solo.

\section{INTRODUCTION}

Weeds are a chronic phytosanitary problem. Every year, and in all crops without exception, management measures are needed for weed control. Weeds may compete with crops for light, water and nutrients, thus reducing crop yields (Gucci et al., 2012; Ferreira et al., 2013; Konvalina et al., 2016). Despite the 36

This is an Open Access article distributed under the terms of the Creative Commons Attribution License (http://creativecommons.org/licenses/by/4.0), which permits unrestricted use, distribution, and reproduction in any medium, provided the original work is properly cited. 
negative impact of weeds in global agriculture, they may also provide important benefits to the ecosystem (Cordeau et al., 2016).

Weeds are a major challenge to farmers, requiring a multitude of cultural tactics to disrupt weed population dynamics. The ancestral methods of weed control are hand weeding and soil tillage. However, in large-scale agriculture, the former is not feasible because of the limited labour available and the associated costs. The potentialities of tillage operations on weed management and related problems have been extensively studied (Brainard et al., 2013; Bajwa, 2014; Anderson, 2015; Legere et al., 2013). Despite the beneficial effect on reducing weed infestation, soil tillage favours soil erosion and presents a high economic and environmental cost which makes it less than suitable to most conservative agricultural systems (Chauhan et al., 2012). Rather, selecting crop rotations of species with different growing cycles, and the varying of sowing dates and planting densities, are weed management strategies which are more acceptable ecologically (Drews et al., 2009; Bajwa, 2014; Garrison et al. 2014; Anderson, 2015; Dorn et al., 2015). However, these practices alone are not usually enough to reduce weed infestation to acceptable levels. In perennial tree crops and vineyards is very usual to manage the weed vegetation by cover cropping with sown species (Monteiro and Lopes, 2007; Rodrigues et al., 2015a,b; Portugal et al., 2017), a system which usually also uses an herbicide to control the weeds in the rows.

Consequently, the use of herbicides has been widespread in large-scale agriculture. However, there is still great pressure to reduce conventional herbicides in that they may lead to herbicide resistance (Portugal et al., 2013), cause phytotoxicity in cultivated plants (Cañero et al., 2011) and may be related to environmental damage (Ghersa et al., 2000; Celis et al., 2007). In addition, herbicides produced from chemical synthesis cannot be used in organic farming, which makes weed control one of the major challenges of this cropping system (Gruber and Chaupein, 2009). In the last decades, a great effort has been devoted in the search for bio-herbicides with the potential to be used in organic agriculture (Pacanoski, 2011; Bailey et al., 2013; Mupondwa et al., 2015; Tigre et al., 2015; Hussain et al., 2017). However, the number of bio-herbicides on the market is limited and represents less than $10 \%$ among biopesticides (Cordeau et al., 2016).
In the NE of Portugal, agriculture is a marginal economic activity due to the poor ecological conditions for plant growth. The main constraint factors are the lack of water for irrigation and the steep slope of the landscapes. In such conditions, grapevine and olive tree are among the few viable crops since they can cope with drought stress and poor soil fertility. Currently, most farmers manage their activities within the European Union rules of Integrated Crop Production in spite of some are trying to adopt less intensive farming system, such as organic farming. In these agricultural systems farmer's income should be based on achieving quality products rather than higher yields. However, the conversion of traditional agriculture to organic farming cannot be an easy task and management of weeds is one of the major challenges. Soil tillage has been extensively questioned since it causes soil erosion (Martínez et al., 2006; Gómez et al., 2009) and reduces soil organic matter and its biological activity (Montanaro et al., 2010; Ramos et al., 2011; Aranda et al., 2011; Ferreira et al., 2013; Rodrigues el al., 2015a). The use of herbicides reduces biodiversity and may also cause other environmental problems (Ghersa et al., 2000; Celis et al., 2007). Cover cropping has been seen as a possible alternative for ground management due to its positive effects on soil fertility. However, cover crops compete for water and nutrients which may reduce crop productivity (Lipecki and Berbeć, 1997; Rodrigues et al., 2011, Ferreira et al., 2013). Methods using thermal means (flaming, hot water, hot foam or laser radiation) usually have a high cost and some cannot be safety used in Mediterranean conditions due to the risk of wildfire. Thus, it seems that the field is open to find new tools to help to manage weed vegetation, in particular in organic farming where conventional herbicides are not allowed.

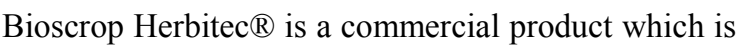
authorized for use in organic farming as a fertilizer in some European countries. Its main composition is 6.0 $\%$ water-soluble potassium oxide, $54.7 \%$ organic acids and $39.3 \%$ of dispersants and diluents. Although developed as a fertilizer, the product can act as an herbicide when applied at certain concentrations. Thus, the objective of this work is to test the potential use of Bioscrop Herbitec on weed management in two perennial crops (grapevine and olive) and in two seasons (winter and spring). The hypothesis under study is that the product can reduce weed competition in cultivated plants ensuring, at the same time, enough vegetation for soil protection and other ecological benefits. 


\section{MATERIAL AND METHODS}

\section{Site characterization}

This project of on-farm research was carried out in two vineyards, one located in Rendufe (Valpaços) and the other in Bragança, and two olive orchards, both located in Valverde (Valpaços). The vineyard of Rendufe is 4 years old and the vineyard of Bragança is 20 . In both vineyards the plants are spaced at $2.5 \times$ $1.4 \mathrm{~m}$. The olive groves are both over 50 years old and the trees spaced at $8 \times 8 \mathrm{~m}$. The product was tested in six different cropping situations as reported in Table I. Currently, the farmers receiving this experiment manage their activities as Integrated Crop Production, but there is a possibility to convert the system to organic farming as soon as they can overcome some cropping constrains, one of the most important being weed management.

The climate of the region is of Mediterranean type with some Atlantic influence. Meteorological data recorded during the experimental period is shown in Figure 1. The soils where the vineyard of Rendufe and the olive groves of Vilaverde are located are classified as eutric orthic Leptosols. The soil of the experiment of Bragança is classified as eutric Cambisol. Selected properties of these soils based on samples collected at the start of the field trials are shown in Table II.

\section{TABLE I}

Experimental field trials arranged by crop, season, year, local and installation date.

Campos experimentais organizados por cultura, estação, ano, local e data de instalação.

\begin{tabular}{lcccc}
\hline Crop & Season & Year & Local & Installation date \\
\hline Olive & Winter & $2015 / 16$ & Valverde1 & Dec $26^{\text {th }}$ \\
Olive & Spring & 2016 & Valverde2 & May 2 \\
Olive & Winter & $2017 / 18$ & Valverde1 & Dec $19^{\text {th }}$ \\
Vine & Winter & $2015 / 16$ & Rendufe & Dec $26^{\text {th }}$ \\
Vine & Winter & $2017 / 18$ & Bragança & Dec $19^{\text {th }}$ \\
Vine & Spring & 2018 & Bragança & Abril 2 \\
\hline
\end{tabular}

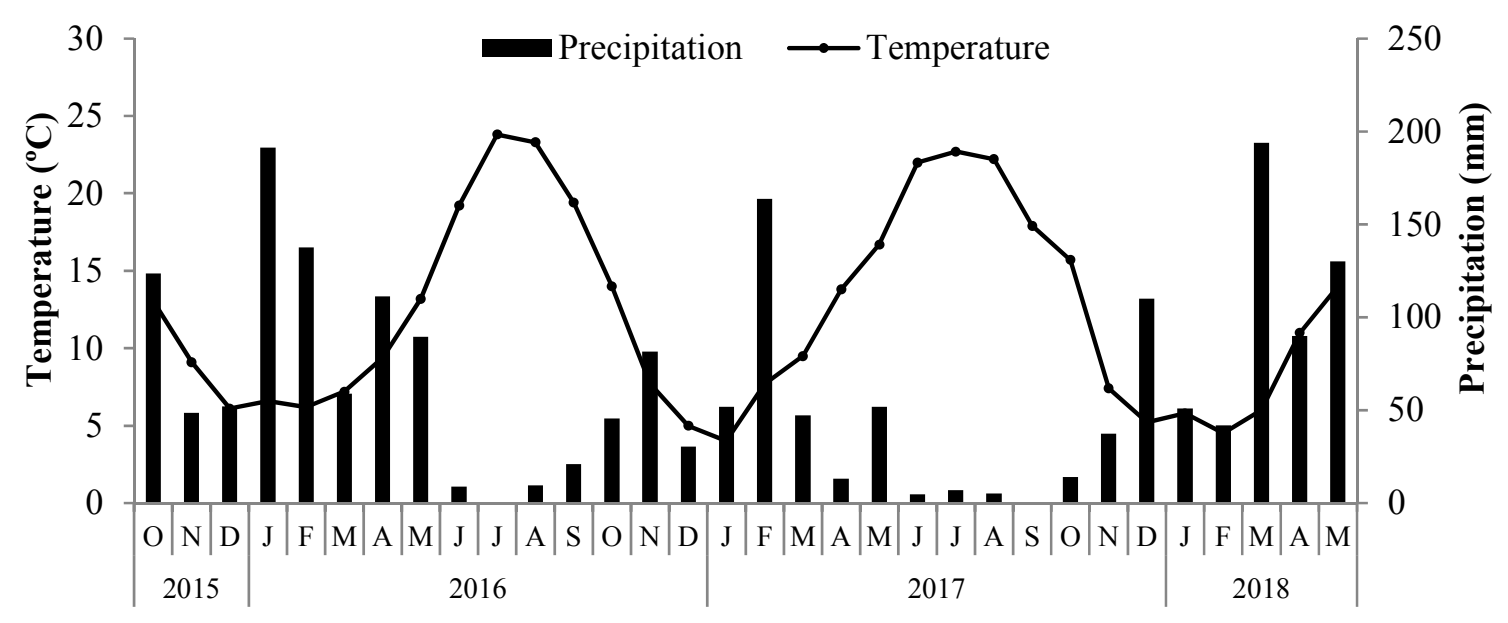

Figure 1. Average monthly temperature and accumulated precipitation recorded in the meteorological station of Santa Apolónia farm in Bragança, NE Portugal, during the experimental period.

Temperatura média do ar e precipitação mensais registadas na estação meteorológica da quinta de Santa Apolónia em Bragança durante o período experimental.

\section{Experimental design and crop management}

The experiments were arranged as randomized block designs with three replicates (3 blocks). In each experiment, three treatments were imposed: control (without application of product); dose 1 (10\% product concentration); and dose 2 (15\%). Each experimental unit consisted of $16 \mathrm{~m}^{2}$ ( $4 \times 4 \mathrm{~m}$ in the olive groves and $8 \times 2 \mathrm{~m}$ in the vineyard). In treated plots of all the experiments the entire soil surface (rows and interrows) was sprayed.

The product is commercially marketed under the trade name Bioscrop Herbitec $\AA$, consisting of $6.0 \%$ water-soluble potassium oxide $\left(\mathrm{K}_{2} \mathrm{O}\right), 54.7 \%$ organic acids and $39.3 \%$ dispersants and diluents. 
Prior to the application of the product a blank test was performed to select the type of nozzle in order to follow the manufacturer's application recommendations. In the application of the product, a manual backpack-type sprayer was used, equipped with Albuz APE $110 \AA$ nozzle, at a pressure of $4 \times 10^{5}$ $\mathrm{Pa}$ and speed of $5 \mathrm{~km} \mathrm{~h}^{-1}$ in order to obtain the volume of spray recommended by the manufacturer.

\section{TABLE II}

Selected properties of soil samples collected in the experimental plots prior to the establishment of the field experiments.

Algumas propriedades dos solos com base em amostras colhidas nos talhões experimentais antes do estabelecimento dos ensaios de campo

\begin{tabular}{lcccc}
\hline Soil properties & Rendufe & Valverde1 & Bragança & Valverde2 \\
\hline $\mathrm{pH}\left(\mathrm{H}_{2} \mathrm{O}\right)$ & 4.87 & 5.12 & 6.00 & 5.05 \\
$\mathrm{pH}(\mathrm{KCl})$ & 3.46 & 4.02 & 5.11 & 4.61 \\
Organic matter $(\%)^{\mathrm{a}}$ & 0.80 & 1.70 & 1.21 & 4.75 \\
Extractable $\mathrm{P}\left(\mathrm{mg} \mathrm{P}_{2} \mathrm{O}_{5} \mathrm{~kg}^{-1}\right)^{\mathrm{b}}$ & 28.0 & 93.0 & 28.0 & 350.0 \\
Extractable K $\left(\mathrm{mg} \mathrm{K}_{2} \mathrm{O} \mathrm{kg}^{-1}\right)^{\mathrm{b}}$ & 127.0 & 76.0 & 70.0 & 300.0 \\
Exchange complex & & & & 2.77 \\
$\mathrm{Ca}\left(\mathrm{Cmol}^{+} \mathrm{kg}^{-1}\right)$ & 0.56 & 0.75 & 10.73 & 0.43 \\
$\mathrm{Mg}\left(\mathrm{Cmol}^{+} \mathrm{kg}^{-1}\right)$ & 0.24 & 0.21 & 3.62 & 1.28 \\
$\mathrm{~K}\left(\mathrm{Cmol}^{+} \mathrm{kg}^{-1}\right)$ & 0.32 & 0.26 & 0.31 & 0.28 \\
$\mathrm{Na}\left(\mathrm{Cmol}^{+} \mathrm{kg}^{-1}\right)$ & 0.28 & 0.38 & 0.38 & 0.10 \\
$\mathrm{Ex} \mathrm{acidity}\left(\mathrm{Cmol}^{+} \mathrm{kg}^{-1}\right)$ & 0.90 & 0.50 & 0.10 & 4.86 \\
$\mathrm{CEC}\left(\mathrm{Cmol}^{+} \mathrm{kg}^{-1}\right)$ & 2.30 & 2.11 & 15.14 &
\end{tabular}

\section{Field determinations}

The evaluation of the effect of the treatments consisted of determining the degree of soil cover by the pin point and grid methods (Damgaard et al., 2011; Rodrigues et al., 2015a,b). The production of biomass was evaluated as a measure of the damage caused to the vegetation. The floristic composition of the experimental plots was also assessed to determine the specific susceptibility of the weeds to the product.

The pin point method measures the proportion of ground occupied by a perpendicular projection on to it of the aerial parts of the plants. A frame with a fixed grid pattern was placed randomly above the vegetation and a pin was inserted vertically through one of the ten $(10 \mathrm{~cm}$ spaced $)$ grid points into the vegetation. The first point touched by the pin (unaffected vegetation, damaged vegetation and bare soil) was registered. In each experiment the frame was randomly placed in five positions within the available area. The grid method consisted of placing a grid of a square meter divided into $5 \mathrm{~cm} \times 5 \mathrm{~cm}$ units on the vegetation. The number of units or their fractions occupied by unaffected vegetation, damaged vegetation or bare soil were recorded.

The dry biomass of weeds was evaluated by cutting the vegetation from a sample of $0.25 \mathrm{~m}^{2}$ after a metal grid $(0.5 \times 0.5 \mathrm{~m})$ had been randomly thrown onto the vegetation. After it had been cut, the vegetation was oven-dried at $70{ }^{\circ} \mathrm{C}$ to constant weight. The floristic composition of the vegetation was assessed by the pin point method. The plants touched by the pin were identified, whenever possible, by species.

\section{Data analysis}

Comparisons among treatments were provided by ANOVA by using JMP statistical Software. Means with significant differences $(\alpha<0.05)$ were separated by Tukey HSD test $(\alpha=0.05)$. In figures, the means were associated to their mean confidence intervals ( $\alpha$ $=0.05)$.

\section{RESULTS AND DISCUSSION}

The two tested dosages of the fertilizer significantly increased the percentage of bare soil for most of the sampling dates, particularly at the highest concentration, when assessed by the pin point method (Figure 2). Weeds were severely damaged immediately after the application of the fertilizer, with tissues showing necrosis caused by the product exceeding $80 \%$ in all trials, and the effect persisted for more than one month. At 113 and 86 days after the application of the fertilizer, respectively in $2015 / 2016$ and 2017/2018, no symptoms of damage on tissues were visible. However, the vegetation did not recover to the levels of development of the control treatment, and the values of bare soil remained significantly higher in treated plots.

The use of the grid method in evaluating the effect of the product application yielded results with a pattern 
similar to that recorded with the pin point method (Figure 3). However, this method resulted in a relative overestimation of the percentage of bare soil associated with the fertilizer treatments and underestimated the damaged vegetation.

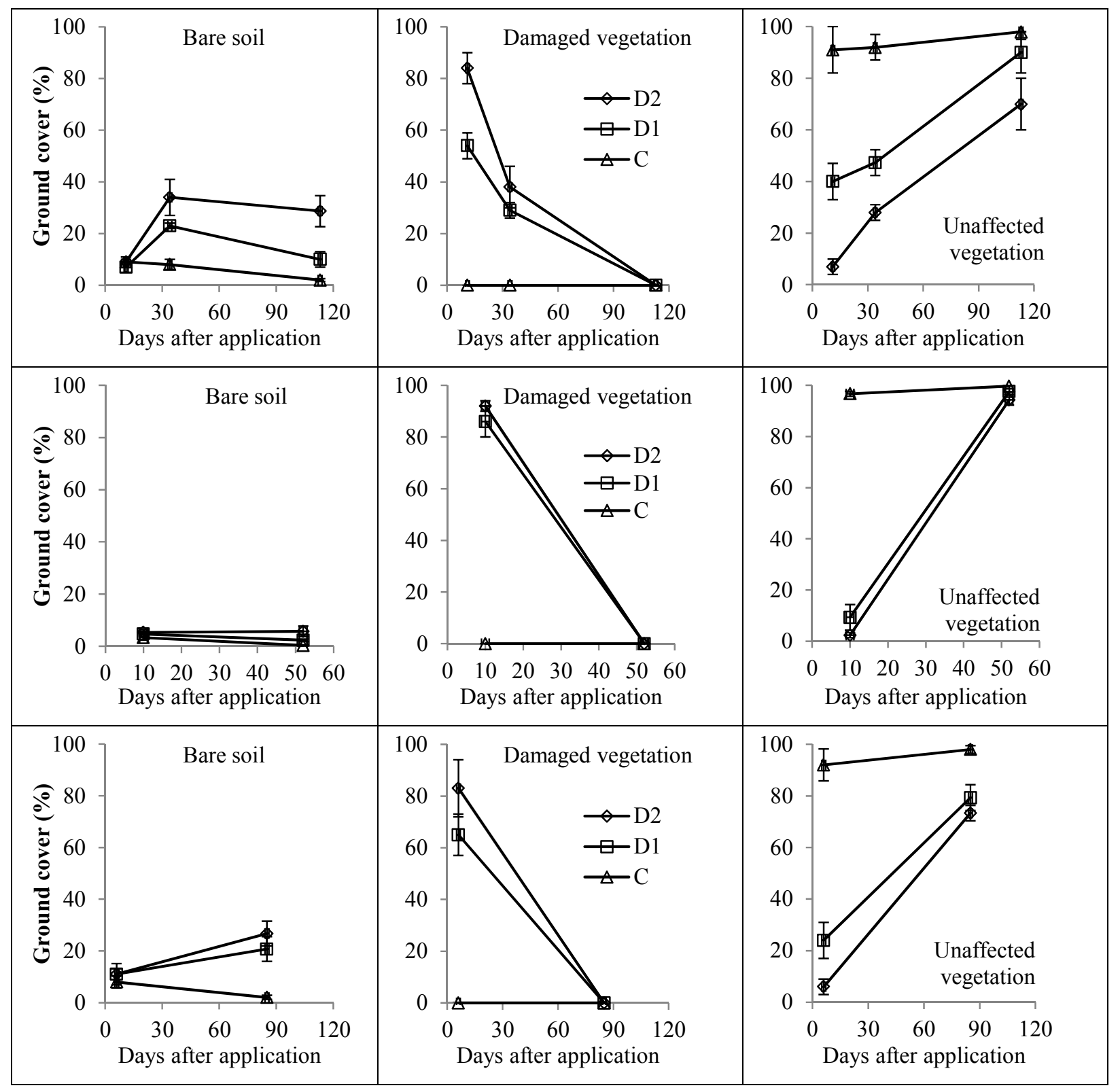

Figure 2. Ground cover (bare soil, damaged, and unaffected vegetation) assessed by the pin point method in olive trials in the winter $2015 / 2016$ (top panels), spring 2016 (middle panels) and winter 2017/2018 (bottom panels) as a function of the application of Bioscrop Herbitec at 10\% (D1) and $15 \%$ (D2) concentrations and in the control treatment. The error bars represent the mean confidence limits $(\alpha=0.05)$.

Cobertura do solo (solo nu, vegetação danificada e não danificada) avaliada pelo método do ponto quadrado em olival no inverno de $2015 / 2016$ (painéis superiores), primavera de 2016 (painéis intermédios) e inverno de 2017/2018 (painéis inferiores) em função da aplicação de Bioscrop Herbitec nas concentrações de 10\% (D1) e 15\% (D2) e na testemunha. As barras de erro representam o intervalo de confiança da média ( $\alpha=$ $0,05)$. 


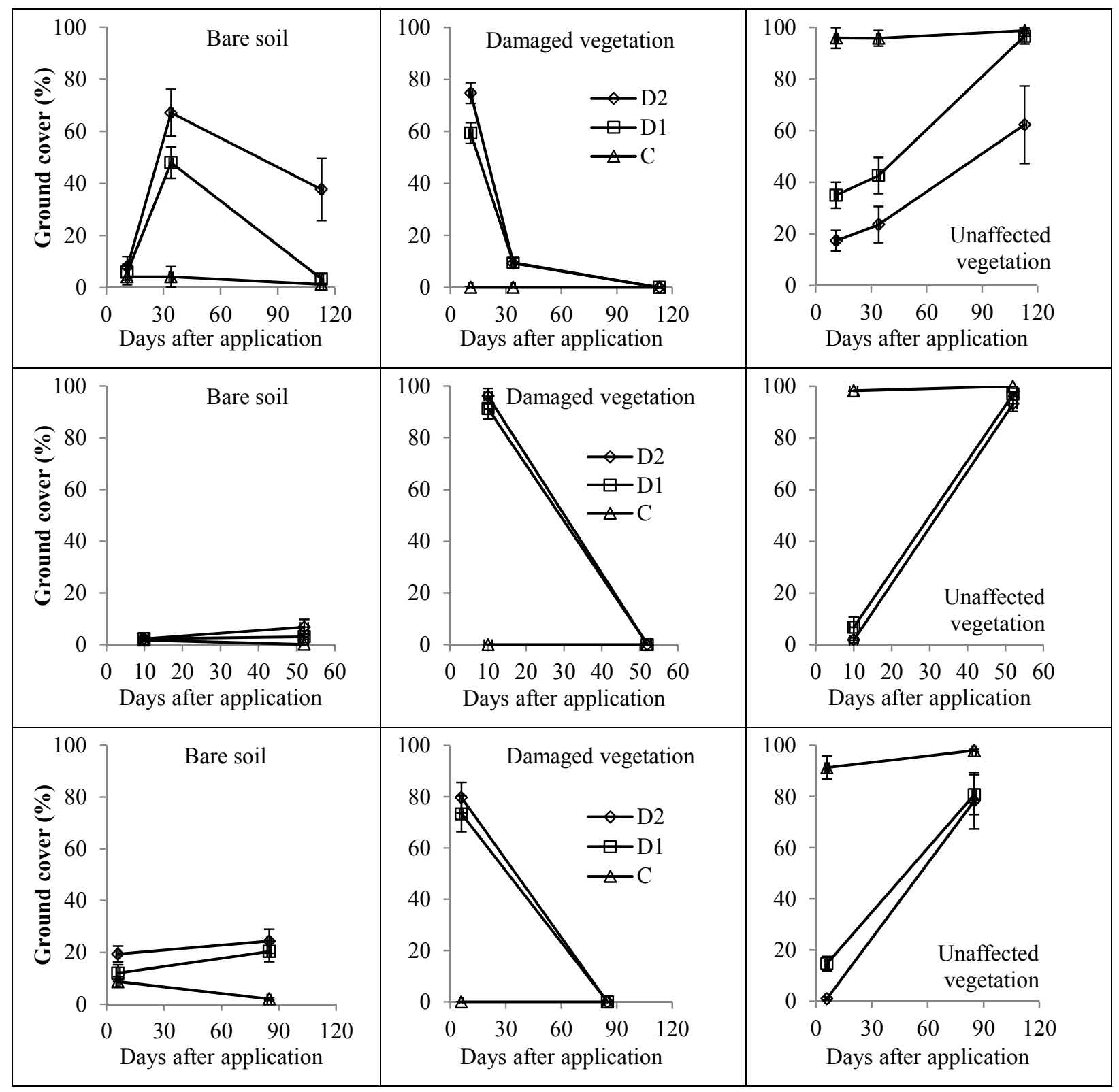

Figure 3. Ground cover (bare soil, damaged, and unaffected vegetation) assessed by the grid method in olive trials in the winter $2015 / 2016$ (top panels), spring 2016 (middle panels) and winter 2017/2018 (bottom panels) as a function of the application of Bioscrop Herbitec at 10\% (D1) and $15 \%$ (D2) concentrations and in the control treatment. The error bars represent the mean confidence limits $(\alpha=0.05)$.

Cobertura do solo (solo nu, vegetação danificada e não danificada) avaliada pelo método da grelha em olival no inverno de $2015 / 2016$ (painéis superiores), primavera de 2016 (painéis intermédios) e inverno de 2017/2018 (painéis inferiores) em função da aplicação de Bioscrop Herbitec

nas concentrações de $10 \%$ (D1) e 15\% (D2) e na testemunha. As barras de erro representam o intervalo de confiança da média ( $\alpha=0,05)$.

The effect of the application of fertilizer recorded on the winter or spring vegetation of the vineyards evolved in a similar trend to that was registered in olive, either by the pin point method (Figure 4) or by the grid method (Figure 5). In winter 2015/2016 the percentage of damaged tissue approached $90 \%$ at the highest dose of product 11 days after its application when assessed by the pin point method (Figure 4). However, a major difference occurred between years. The lack of rain in autumn/winter of 2017/2018 (Figure 1) severely impaired the development of the vegetation. Thus, in these conditions, the use of this product did not reach values of vegetative damage similarly high to the previous years since most of the 
observations fell on bare soil. The spring of 2018 was characterized by high and persistent precipitation originating a boom on the development of vegetation, which reduced the damage recorded on weeds and the duration of the herbicidal effect of both dosages of the Bioscrop Herbitec ${ }^{\circledR}$.

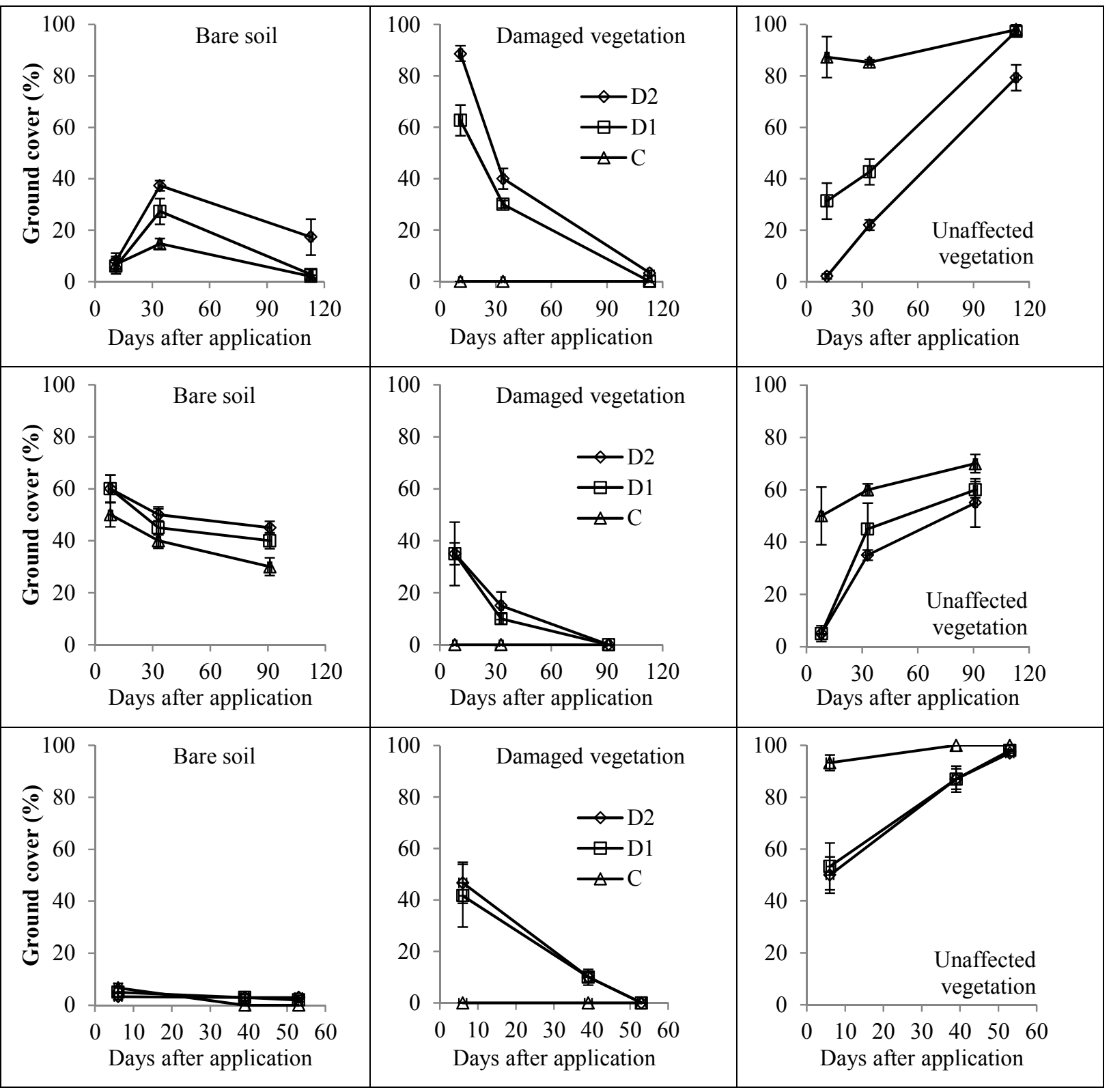

Figure 4. Ground cover (bare soil, damaged, and unaffected vegetation) assessed by the pin point method in vineyard trials in the winter 2015/2016 (top panels), winter 2017/2018 (middle panels) and spring 2018 (bottom panels) as a function of the application of Bioscrop Herbitec at $10 \%$ (D1) and $15 \%$ (D2) concentrations and in the control treatment. The error bars represent the mean confidence limits $(\alpha=0.05)$.

Cobertura do solo (solo nu, vegetação danificada e não danificada) avaliada pelo método do ponto quadrado em vinha no inverno de $2015 / 2016$ (painéis superiores), primavera de 2016 (painéis intermédios) e inverno de 2017/2018 (painéis inferiores) em função da aplicação de Bioscrop Herbitec nas concentrações de $10 \%$ (D1) e $15 \%$ (D2) e na testemunha. As barras de erro representam o intervalo de confiança da média ( $\alpha=0,05)$. 


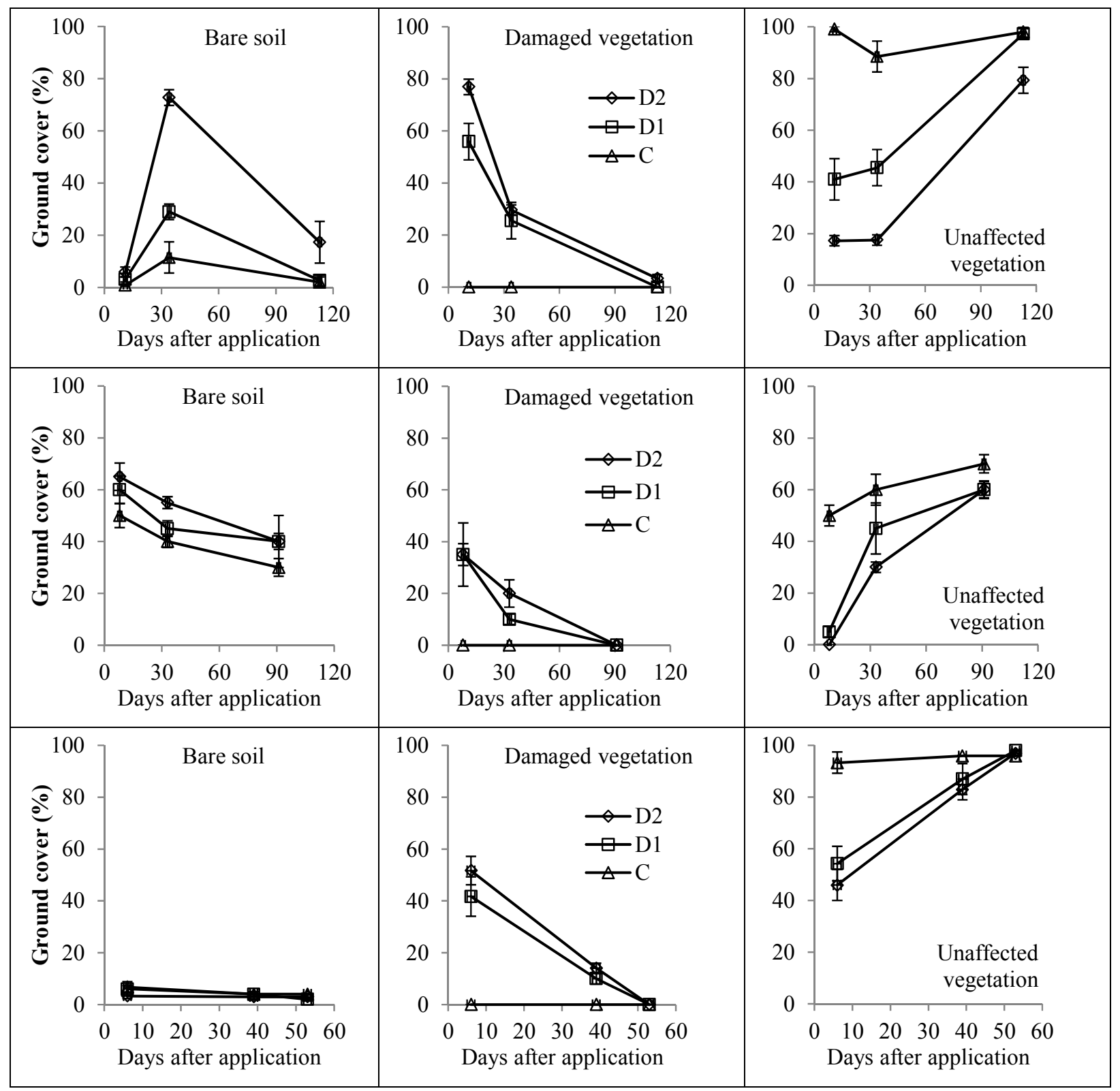

Figure 5. Ground cover (bare soil, damaged, and unaffected vegetation) assessed by the grid method in vineyard trials in the winter $2015 / 2016$ (top panels), winter 2017/2018 (middle panels) and spring 2018 (bottom panels) vineyard trials as a function of the application of Bioscrop Herbitec at $10 \%$ (D1) and $15 \%$ (D2) concentrations and in the control treatment. The error bars represent the mean confidence limits ( $\alpha=0.05)$.

Cobertura do solo (solo nu, vegetação danificada e não danificada) avaliada pelo método da grela em vinha no inverno de $2015 / 2016$ (painéis superiores), primavera de 2016 (painéis intermédios) e inverno de 2017/2018 (painéis inferiores) em função da aplicação de Bioscrop Herbitec nas concentrações de $10 \%$ (D1) e 15\% (D2) e na testemunha. As barras de erro representam o intervalo de confiança da média ( $\alpha=0,05)$.

The effect on dry matter yield of herbaceous vegetation due to the use of the two high dosages of the Bioscrop Herbitec ${ }^{\circledR}$ was assessed by periodic cuts of the aboveground biomass. The use of the two high dosages of the fertilizer gave a significant reduction in dry matter yield of weeds in all experiments and the detrimental effect persisted at the end of each experiment (Figure 6). The production of dry matter by weeds was particularly low in the winter of $2017 / 2018$ due to the lack of precipitation, but still the herbicidal effect was significant. 


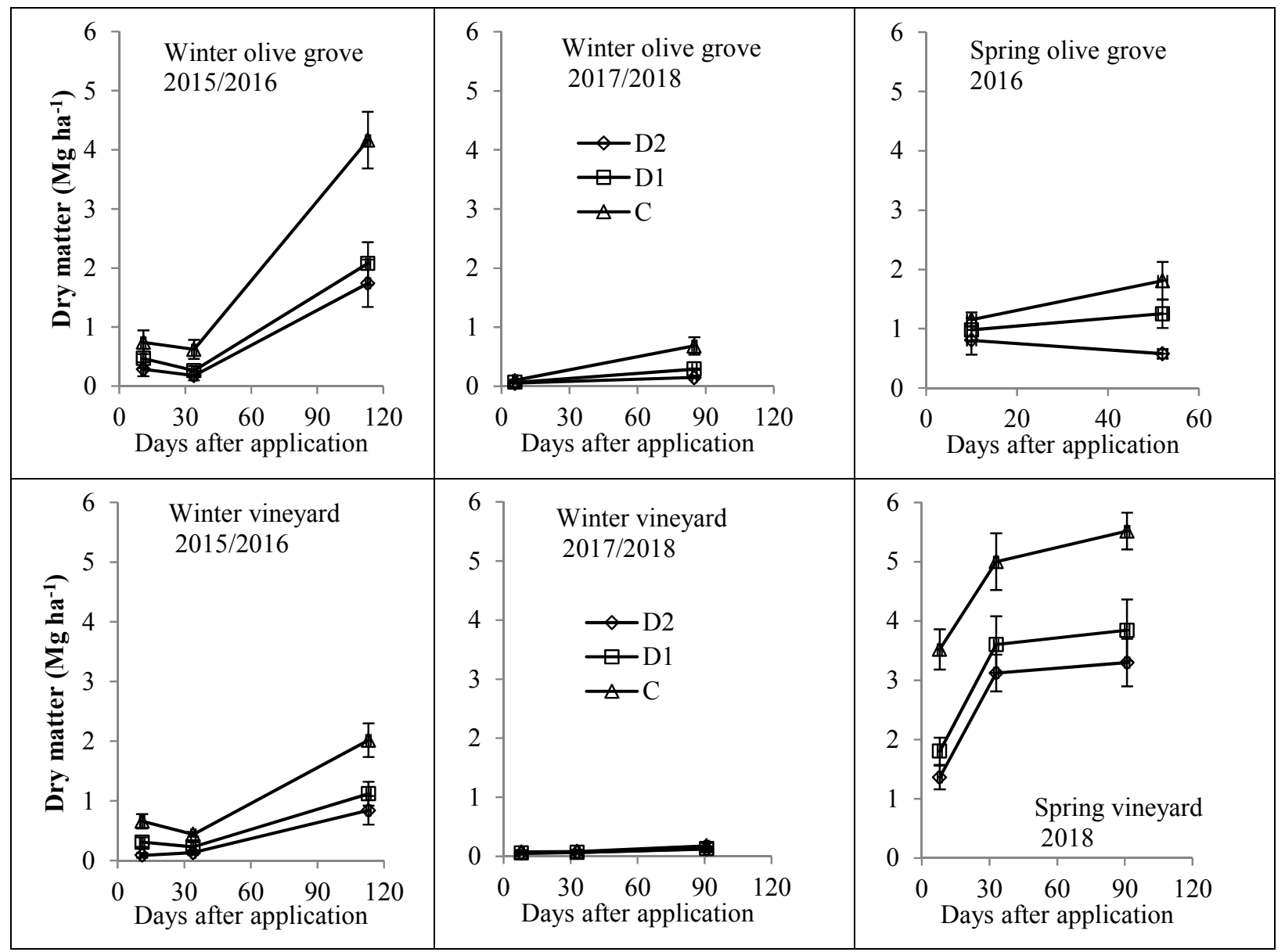

Figure 6. Dry matter dynamic after the application of Bioscrop Herbitec at 10\% (D1) and 15\% (D2) concentrations and in the control treatment in the six field trials. The error bars represent the mean confidence limits $(\alpha=0.05)$.

Dinâmica da matéria seca após a aplicação de Bioscrop Herbitec nas concentrações de 10\% (D1) e 15\% (D2) e na testemunha nos seis ensaios de campo. As barras de erro representam o intervalo de confiança da média $(\alpha=0.05)$.

The reported results showed that the applied product had an effect comparable to that of a non-selective contact herbicide, i.e. it caused damage on the tissues touched by the spray. The product showed potential for use in agroecosystems where the objective is to reduce the competitive effect of weeds without exposing the soil to erosion and without reducing biodiversity. By using this product the soil maintained a vegetative coverage over time. It is well documented that vegetation is important in reducing the risk of soil erosion (Martínez et al., 2006; Gómez et al., 2009) as well as improving soil organic matter and soil biological activity (Moreno et al., 2009; Montanaro et al., 2009; Ramos et al., 2011; Ferreira et al., 2013; Rodrigues et al., 2015a). However, excessive vegetation competes with resources and can reduce crop yields (Anderson et al. 1992; Lipecki and Berbeć, 1997; Gucci et al., 2012; Ferreira et al., 2013). Thus, the product may be of interest in agricultural contexts where only a slight suppressive effect on the vegetation is desired, instead of a definitive and severe effect as generally caused by conventional herbicides. This product is currently allowed for organic farming as a fertilizer in Spain. If its application as an herbicide results on effective weed control, the interest in it by farmers can increase and the registration as herbicide should be considered. However, further studies are needed to ensure that no residues appear in the grapes or in the olives.

The pin point and grid methods yielded results with a similar pattern, although the pin point method estimated greater damage to the vegetation. The results of the dry matter evaluation were also in line with the above mentioned faster field methods. Although the pin point method is the most popular among researchers (Damgaard et al., 2011; Rodrigues 
et al., 2015a,b), the grid method seems also reliable and can be used whenever it is easy to implement.

The application of the fertilizer in the tested dosages influenced the dynamic of a large number of weeds present in ground cover (Figure 7). Vicia sativa L., Tolpis barbata (L.) Gaertn, Erodium moschatum (L.) L'Hér., Ornithopus sativus Brot. Vulpia bromoides (L.) Gray and Crepis capillaris (L.) Wallr. were negatively affected and reduced their presence on the cover due to the application of the herbicide in comparison to the control. In contrast, Brassica barrelieri (L.) Janka, Medicago nigra (L.) Krock., Anthemis arvensis L., Conyza canadensis (L.) Cronquist, Calendula arvensis L. and Raphanus raphanistrum $\mathrm{L}$. increased their relative presence in

the treated plots in relation to the control. Several other species were recorded in the covers, in control but also in the treated plots. Their relative abundance, however, was usually lower than that of the species presented in Figure 7 or their dynamic did not change with the application of the fertilizer. Those that the botanical identification was possible and found in the experimental plots were Sonchus oleraceus L., Lolium rigidum Gaudin, Mibora minima (L.) Desv., Calendula arvensis L., Stellaria media (L.) Vill., Coleostephus myconis (L.) Rchb.f., Geranium molle L., Rumex bucephalophorus L., Avena barbata Pott ex Link, Chondrilla juncea L., Hypochaeris radicata L., Convolvulus arvensis L. and Chenopodium album L.

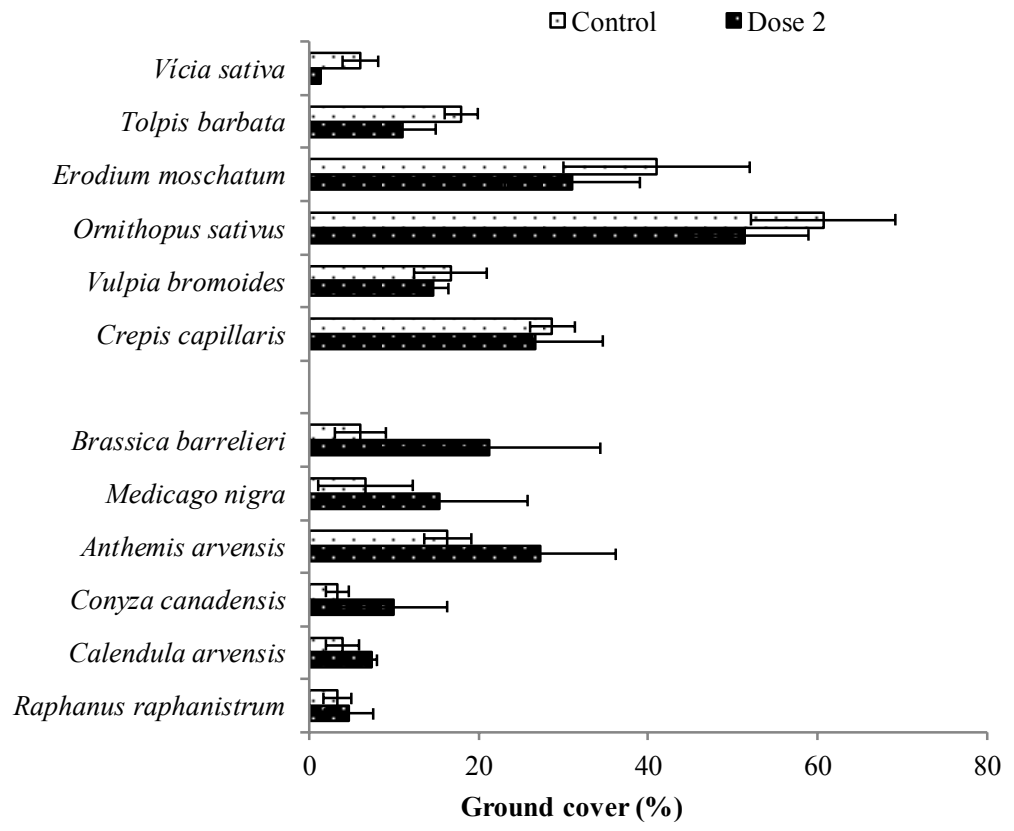

Figure 7. Effect of the application of Bioscrop Herbitec at $15 \%$ concentration (D2) and control treatment on various weed species. The figure combines all the results from the six field experiments. The upper group identifies species that reduced their presence on the cover relative to the control. The bottom group identifies species that have gained relative relevance on the cover in treated plots in comparison to the control. The error bars represent the mean confidence limits $(\alpha=0.05)$.

Efeito do Bioscrop Herbitec na concentração de $15 \%$ (D2) e da testemunha em várias espécies infestantes. A figura combina todos os resultados dos seis ensaios de campo. O grupo superior identifica espécies que reduziram a sua presença no coberto em comparação com a testemunha. $O$ grupo de baixo identifica espécies que ganharam relevância no coberto nos talhões tratados em comparação com a testemunha. As barras de erro representam o intervalo de confiança da média $(\alpha=0,05)$.

The use of herbicides, as with any other method of weed vegetation management, alters biological balance, and may limit or favor certain species (Rodrigues et al., 2009). Some plants were less damaged by the herbicide or recovered more quickly from the damage suffered. These species arose in greater relative abundance in the treated plots relative to the control. Theoretically, the product used in this study should preferably be used in covers dominated by susceptible species. Otherwise, some less susceptible species may become particularly abundant and dominate the cover. In these experiments, some 
of species whose relative abundance was reduced by the application of the high dosages of the fertilizer were $V$. sativa, T. barbata, E. moschatum, O. sativus, $V$. bromoides and C. capilaris.

\section{CONCLUSIONS}

The product Bioscrop Herbitec ${ }^{\circledR}$ caused damage to the weed vegetation capable of reducing competition with the cultivated plants even when used at the lower dose. It appears to be a product with potential to be used as a contact herbicide when only a slight suppressing effect on weed vegetation is desired, without causing severe and permanent damage on it, while maintaining a satisfactory soil cover.

\section{REFERENCES}

Anderson J.L., Bingham G.E., Hill R.W., 1992. Effect of permanent cover crop competition on sour cherry tree evapotranspiration, growth, and productivity. Acta Hort., 313, 135142 .

Anderson R.L., 2015. Integrating a complex rotation with no-till improves weed management in organic farming. A review. Agron Sustain Dev., 35, 967-974.

Aranda V., Ayora-Cañada M.J., Domínguez-Vidal A., MartínGarcía J.M., Calero J., Delgado R., Verdejo T., González-Vila F.J., 2011. Effect of soil type and management (organic vs. conventional) on soil organic matter quality in olive groves in a semi-arid Environment in Sierra Mágina Natural Park (S Spain). Geoderma, 164, 54-63.

Bailey K.L., Falk S., Derby J.-A., Melzer M., Boland G.J., 2013. The effect of fertilizers on the efficacy of the bioherbicide, Phoma macrostoma, to control dandelions in turfgrass. Biol. Control, 65, 147-151.

Bajwa A.A., 2014. Sustainable weed management in conservation agriculture. Crop Prot., 65, 105-113.

Brainard D.C., Peachey E., Haramoto E., Luna J., Rangarajan A., 2013. Weed ecology and management under strip tillage: implications for Northern U.S. vegetable cropping systems. Weed Technol., 27, 218-230.

Portugal J., Calha I.M., Gonzallez-Torrava, F., Roldan R., Deprado R., 2013. Resistência ao glifosato em vinhas do Douro. Actas do $9^{\circ}$ Simpósio de Vitivinicultura do Alentejo, 15-17 maio, Évora, Portugal. pp. 139-148.

Portugal J., Monteiro A., Luz J.P., 2017. Gestão de infestantes em vinhas, olivais e pomares. Rev. Ciênc. Agár., 40(4), 839-853.

Cañero A.I., Cox L., Redondo-Gómez S., Mateos-Naranjo E., Hermosín M.C., Cornejo J., 2011. Effect of the herbicides Terbuthylazine and Glyphosate on photosystem II photochemistry of young olive (Olea europaea) plants. J. Agric. Food Chem., 59, 5528-5534.

Celis R., Trigo C., Facenda G., Hermosín M.C., Cornejo J., 2007. Selective modification of clay minerals for the adsorption of herbicides widely used in olive groves. J. Agric. Food Chem., 55, 6650-6658.
The application of the product penalized some weeds and benefited others in relative terms, indicating that their efficacy may depend on the type of infestation present.

\section{ACKNOWLEDGMENTS}

The authors are grateful to the Foundation for Science and Technology (FCT, Portugal) and FEDER under Programme PT2020 for financial support to CIMO (UID/AGR/00690/2013).

The results of the first year of studies of this work were extracted from the master's thesis in Agroecology of the first author (António Barreira).

Chauhan B.S., Singh R.G., Mahajan G., 2012. Ecology and management of weeds under conservation agriculture: A review. Crop Prot., 38, 57-65.

[CMV] Câmara Municipal de Valpaços. 2006. Plano Municipal de Defesa da Floresta Contra Incêndios [Municipal Forest Fire Protection Plan]. [Accessed 2016, May 31]. http://valpacos.pt/. Portuguese.

Cordeau S., Triolet M., Wayman S., Steinberg C., Guillemin J.-P., 2016. Bioherbicides: Dead in the water? A review of the existing products for integrated weed management. Crop Prot., 87, 44-49.

Damgaard C., Merlin A., Mesléard F, Bonis A., 2011. The demography of space occupancy: measuring plant colonization and survival probabilities using repeated pin-point measurements. Methods Ecol. Evol., 2, 110-115.

Dorn B., Jossi W., Van Der Heijden M.G.A., 2015. Weed suppression by cover crops: comparative on-farm experiments under integrated and organic conservation tillage. Weed Res., 55, 586-597.

Drews S., Neuhoff D., Köpke U., 2009. Weed suppression ability of three winter wheat varieties at different row spacing under organic farming conditions. Weed Res., 49, 526-533.

Ferreira I.Q., Arrobas M., Claro A.M.., Rodrigues M.A., 2013. Soil management in rainfed oliv,e orchards may result in conflicting effects on olive production and soil fertility. Span. J. Agric. Res. 11(2), 472-480

Garrison A.J., Miller A.D., Ryan M.R., Roxburgh S.H., Shea K., 2014. Stacked crop rotations exploit weed-weed competition for sustainable weed management. Weed Sci., 62, 166-176.

Ghersa C.M., Benech-Arnolds R.L., Satorre E.H., Martínez-Ghersa M.A., 2000. Advances in weed management strategies. Field Crop Res., 67, 95-104.

Gómez J.A., Guzmán M.G., Giráldez J.V., Ferreres E., 2009. The influence of cover crops and tillage on water and sediment yield, and on nutrient, and organic matter losses in an olive orchard on a sandy loam soil. Soil Till. Res., 106, 137-144.

Gruber S., Claupein W., 2009. Effect of tillage intensity on weed infestation in organic farming. Soil Till. Res., 105, 104-111.

Gucci R., Caruso G., Bertolla C., Urbani S., Tatichi A., Esposto S., Servili M., Sifola M.I., Pellegrini S., Pagliai M., Vignozzi N., 2012. Changes of soil properties and tree performances induced by soil 
management in a high density olive orchard. Eur. J. Agron., 41, 1827.

Hussain I., Singh N.B., Singh A., Singh H., 2017. Allelopathic potential of sesame plant leachate against Cyperus rotundus L. Ann. Agrar. Sci., 15, 141-147.

Konvalina P., Kopecký M., Bernas J., Moudrý J., Suchý K., Machková B., 2016. Weed competitiveness of winter and spring wheat in organic farming. Lucrări Ştiințifice. 59, 103-108.

Legere A., Shirtliffe S.J., Vanasse A., Gulden R.H., 2013. Extreme grain based cropping systems: when herbicide-free weed management meets conservation tillage in Northern climates. Weed Technol., 27, 204-211.

Lipecki J., Berbeć S., 1997. Soil management in perennial crops: orchards and hop gardens. Soil Till. Res., 43, 169-184.

Martínez J.R.F., Zuazo V.H.D., Raya A.M., 2006. Environmental impact from mountainous olive orchard under different soil management systems (SE Spain). Sci. Total Environ., 358, 46-60.

Montanaro G., Celano G., Dichio B., Xiloyannis C., 2010. Effect of soil-protecting agricultural practices on soil organic carbon and productivity in fruit tree orchards. Land Degrad. Dev., 21, 132-138.

Monteiro A., Lopes C.M., 2007. Influence of cover crops on water use and performance of vineyard in Mediterranean Portugal. Agric. Ecosyst. Environ., 121, 336-342.

Moreno B., Garcia-Rodriguez S., Cañizares R., Castro J., Benítez E., 2009. Rainfed olive farming in South-eastern Spain: long-term effect of soil management on biological indicators of soil quality. Agr. Ecosyst. Environ., 131, 333- 339.

Mupondwa E., Li X., Boyetchko S., Hynes R., Geissler J., 2015. Technoeconomic analysis of large scale production of pre- emergent Pseudomonas fluorescens microbial bioherbicide in Canada. Bioresour. Technol., 175, 517-528.

Pacanoski Z., 2011. Bioherbicides - a real or virtual measure for efficient weed control? Herbologia, 12, 103-114.

Ramos M.E., Robles A.B., Sánchez-Navarro A., González-Rebollar J.L., 2011. Soil responses to different management practices in rainfed orchards in semiarid environments. Soil Till. Res., 112, 8591.

Rodrigues M.A., Cabanas J., Lopes J.I., Pavão F., Aguiar C.F., Arrobas M., 2009. Ground cover and dynamic of weeds after the introduction of herbicides as soil management systems in rainfed olive orchards. Rev. Ciênc. Agrár., XXXII(2), 30-42.

Rodrigues M.A., Dimande P., Pereira E., Ferreira I.Q., Freitas S., Correia C.M., Moutinho-Pereira J., Arrobas M., 2015a. Earlymaturing annual legumes: an option for cover cropping in rainfed olive orchards. Nutr. Cycl. Agroecosys., 103, 153-166.

Rodrigues M.A., Ferreira I.Q., Freitas S., Pires J., Arrobas M., 2015b. Self-reseeding annual legumes for cover cropping in rainfed managed olive orchards. Spanish J. of Agric.Res., 13(2), e0302, 13 pages.

Rodrigues M.A., Lopes J.I., Pavão F.M., Cabanas J.E., Arrobas M., 2011. Effect of soil management on olive yield and nutritional status of trees in rainfed orchards. Commun. Soil Sci. Plant Anal., 42, 993-2011.

Tigre R.C., Pereira E.C., da Silva N.H., Vicente C., Legaz M.E., 2015. Potential phenolic bioherbicides from Cladonia verticillaris produce ultrastructural changes in Lactuca sativa seedlings. S. Afr. J. Bot., 98, 16-25. 